\title{
Optimized RNA Gel-Shift and UV Cross-Linking Assays for Characterization of Cytoplasmic RNA-Protein Interactions
}

BioTechniques 27:1032-1042 (November 1999)

\author{
A.M. Thomson, J.T. Rogers ${ }^{1}$, \\ C.E. Walker, J.M. Staton and \\ P.J. Leedman \\ Royal Perth Hospital, Perth, \\ WA, Australia, ${ }^{1}$ Brigham and \\ Women's Hospital and \\ Harvard Medical School, \\ Boston, MA, USA
}

\begin{abstract}
Considerable interest has recently focused on defining the mechanisms involved in the regulation of gene expression at the level of $m R N A$ stability and translational efficiency. However, the assays used to directly investigate interactions between RNA and cytoplasmic proteins have been difficult to establish, and methods are not widely available. Here, we describe a robust method for RNA electrophoretic mobility shift and UV cross-linking assays that allows rapid detection of cytoplasmic RNA-protein interactions. For added convenience to new investigators, these assays use mini-gels with an electrophoresis time of 15-20 min, enabling a high throughput of samples. The method works successfully with many different probes and cytoplasmic extracts from a variety of cell lines. Furthermore, we provide a system to optimize characterization of the RNA-protein complex and troubleshoot most assay difficulties.
\end{abstract}

\section{INTRODUCTION}

mRNA stability and translational efficiency are now recognized as major control points in the regulation of gene expression. The half-life of most mRNA species is determined by a complex set of interactions that depend on the primary and secondary structure of the mRNA, ribonuclease activity, RNAbinding proteins, translational rate and its cytoplasmic location. Regulation of posttranscriptional gene expression by RNA sequences is a rapidly expanding field, with increasing characterization of functionally important cis-acting elements within the primary RNA sequence, as well as the identification of cytoplasmic trans-acting proteins that specifically bind these cis-acting regions using RNA electrophoretic mobility shift assay (REMSA; RNA gel-shift) and UV cross-linking assay $(1,12)$. These include a family of adenine-uridine (AU)-rich RNA-binding proteins (AUBFs) that interact with mRNAs containing multiple AUUUA sequences $(4,9)$ and the iron regulatory protein (IRP) that binds to the highly conserved stem loops, the iron-responsive elements (IREs), in ferritin and transferrin receptor mRNAs $(2,8,9,11,12,17)$.

Successful identification and characterization of specific trans-acting RNAbinding proteins that bind to functionally important cis-acting elements has proven difficult. This has been largely due to RNase degradation and other difficulties in establishing the techniques involved. To date, a simple, reliable and robust protocol has not been widely available for these assays, though more detailed reviews on each of the subjects addressed in this paper are available $(3,6,15,19,20)$. Currently, we are study- ing the mechanisms involved in the posttranscriptional regulation of several genes, including IRP/IRE interactions in ferritin mRNA, the regulation of thyrotropin $\beta$-subunit expression in the pituitary and epidermal growth factor receptor (EGF-R) mRNA stability in cancer cells. We have developed a method for the REMSA and UV cross-linking assay that is dependable, rapid, easy to use and applicable to the study of many different mRNA species and their cytoplasmic binding proteins from a variety of mammalian cell lines and tissues. Significantly, we have shortened the time required for the REMSA and UV cross-linking assay to 15-20 min by adapting them to a mini-gel apparatus. We also provide a system for optimizing the resolution of the RNA-protein complexes and the ground rules for effective troubleshooting in the assays.

\section{MATERIALS AND METHODS}

\section{Cell Culture and Cytoplasmic Protein Extract}

Breast cancer cells (MDA-MB-468) (HTB 132; ATCC, Rockville, MD, USA) were cultured in Dulbecco's modified Eagles medium (DMEM; Life Technologies, Gaithersburg, MD, USA) with $10 \%$ fetal calf serum (FCS) and $1 \%$ penicillin/streptomycin. Rat pituitary (GH3) (CCL82.1; ATCC) cells were grown in DMEM (low glucose) with $10 \% \mathrm{FCS}$ and $1 \%$ penicillin/streptomycin. Human HL60 (CCL 240; ATCC) cells were grown in RPMI 1640 with $20 \%$ FCS and $1 \%$ penicillin/streptomycin. TtT97 thyrotroph cells were derived from primary culture of tumors removed from hypothyroid LAF1 mice and maintained at $10^{7}$ cells $/ \mathrm{mL}$ in 
DMEM with $10 \%$ FCS and $1 \%$ penicillin/streptomycin. Cells were grown to $80 \%$ confluency on $100 \mathrm{~mm}^{2}$ culture dishes. Cytoplasmic extracts were prepared after washing the cells in phosphate-buffered saline (PBS) and lysing in $400 \mu \mathrm{L}$ cytoplasmic extraction buffer (CEB; $10 \mathrm{mM}$ Hepes, pH 7.5, $3 \mathrm{mM}$ $\mathrm{MgCl}_{2}, 14 \mathrm{mM} \mathrm{KCl}, 5 \%$ glycerol, $0.2 \%$ Nonidet ${ }^{\circledR}$ P-40, $1 \mathrm{mM}$ dithiothreitol [DTT]) with freshly added protease inhibitors $(0.5 \mathrm{mM}$ phenylmethylsulfonyl fluoride [PMSF], $10 \mu \mathrm{g} / \mathrm{mL}$ leupeptin, 2 $\mu \mathrm{g} / \mathrm{mL}$ aprotonin [Sigma, St. Louis, MO, USA]). Cell membranes were pelleted (for $120 \mathrm{~s}$ at $8500 \times g$ at $4^{\circ} \mathrm{C}$ ), and the protein supernatant was stored as 30 $\mu \mathrm{L}$ aliquots at $-80^{\circ} \mathrm{C}$ after snap-freezing with liquid nitrogen. Protein concentrations were carefully estimated by the Bradford method (Bio-Rad Laboratories, Hercules, CA, USA) to ensure a consistent protein concentration in REMSA and UV cross-linking assay.

\section{Radiolabeled and Non-Radiolabeled RNA Transcripts}

All plasmid constructs were made by subcloning specific cDNA fragments of interest into Bam HI/HindIII digested pBluescript $^{\circledR}$ II $\mathrm{KS}^{+}$(Stratagene, La Jolla, CA, USA). DNA templates were digested to generate the following sense copy (c) RNA transcripts using T7 polymerase. The rat ferritin IRE probe is an 80-nucleotide (nt) transcript, the EGFreceptor sequence (probe $2 \mathrm{~A}$ ) comprises $80 \mathrm{nt}$ from the $3^{\prime}$ untranslated region (UTR) of the EGF-receptor gene (13) and the rat TSH $\beta$ probe containing the entire 3' UTR of $70 \mathrm{nt}$ (10).

Briefly, 0.2-1 $\mu \mathrm{g}$ of HindIII linearized plasmid DNA was transcribed in a $10 \mu \mathrm{L}$ reaction volume with $1 \mathrm{UT} 7$ RNA Polymerase (Life Technologies) at $37^{\circ} \mathrm{C}$ for $60 \mathrm{~min}$ in the presence of $100 \mu \mathrm{Ci}[\alpha-32$ P]UTP (Amersham Pharmacia Biotech, Little Chalfont, Bucks,
England, UK) and $2.5 \mathrm{mM}$ each of rATP, rCTP and rGTP (Amersham Pharmacia Biotech, Uppsala, Sweden) and $20 \mathrm{mM}$ DTT. One unit of DNase 1 (RNase free) (Promega, Madison, WI, USA) was added for $10 \mathrm{~min}$ at $37^{\circ} \mathrm{C}$, followed by $5 \mathrm{~min}$ at $65^{\circ} \mathrm{C}$. Loading dye $(12 \mu \mathrm{L}$ of $95 \%$ formamide, $20 \mathrm{mM}$ EDTA, $0.3 \%$ bromophenol blue and xylene cyanol [wt/vol]) were added to each tube, which was heated to $80^{\circ} \mathrm{C}$ for $3 \mathrm{~min}$, before resolving labeled RNAs on a $100 \times 80 \times 1.5 \mathrm{~mm} 7 \mathrm{M}$ urea/6\% polyacrylamide (19:1, acrylamide:bis-acrylamide) mini-gel (BioRad Laboratories, pre-electrophoresed in $1 \times$ TBE [ $90 \mathrm{mM}$ Tris borate, $0.2 \mathrm{mM}$ EDTA] at $200 \mathrm{~V}$ for $20 \mathrm{~min}$ ).

Radiolabeled transcripts were visualized using a 2 min exposure of the wet gel to X-ray film. The full-length transcript was excised and eluted from the gel slice by shaking at $1500 \mathrm{rpm}$ for $4 \mathrm{~h}$ at $22^{\circ} \mathrm{C}$ in sterile $0.5 \mathrm{M}$ ammonium 
acetate, 1 mM EDTA. RNA transcripts were recovered by ethanol precipitation $\left(1-4 \times 10^{10} \mathrm{cpm} / \mu \mathrm{g}\right.$ RNA; 30\%-50\% incorporation), resuspended in $80 \mu \mathrm{L}$ $\mathrm{H}_{2} \mathrm{O}$ (treated with diethyl pyrocarbonate [DEPC] ) and stored in aliquots at $-80^{\circ} \mathrm{C}$.

In our experience, riboprobes with specific activities above $1 \times 10^{10} \mathrm{cpm} /$ $\mu \mathrm{g}$ RNA work best. Routinely, non-radiolabeled transcripts were synthesized using the same procedure as for [32P]UTP radioactive probes, but with the inclusion of $2.5 \mathrm{mM}$ uridine $5^{\prime}$ triphosphate (UTP), column purified (Sephadex ${ }^{\circledR}$ G-50; Amersham Pharmacia Biotech) and quantitated at $260 \mathrm{~nm}$.

An alternative approach for probe labeling is to use the Milligan method (14). In this technique, two DNA oligomers are synthesized. One oligomer contains $17 \mathrm{nt}$ of the recognition sequence for $\mathrm{T} 7$ polymerase at the $5^{\prime}$ end and the sequence of interest at the $3^{\prime}$ end. A shorter oligomer encodes complementary sequence to the T7 RNA polymerase binding site. The oligomers are annealed, and after the addition of T7 RNA polymerase and appropriate nucleotides and buffers, the transcription reaction proceeds as above. This method avoids vector subcloning and makes possible rapid characterization of binding sites. However, this oligomerbased method has not reliably generated probes of the same specific activity as achieved using vector-based synthesis.

\section{REMSA}

For REMSA, cytoplasmic extract (2-20 $\mu \mathrm{g})$ was incubated with varying amounts $\left(2-10 \times 10^{4} \mathrm{cpm}, 2.5-10 \mathrm{pg}\right)$ of radiolabeled transcript for $30 \mathrm{~min}$ at $22^{\circ} \mathrm{C}$ in a reaction volume of $10 \mu \mathrm{L}$ made up with CEB $(10,11)$. Subsequently, RNase T1 (0-1 U) was added to the mixture for $10 \mathrm{~min}$ at $22^{\circ} \mathrm{C}$, followed by heparin $(0-10 \mu \mathrm{g} / \mu \mathrm{L})$ (Sigma) for $10 \mathrm{~min}$ at $22^{\circ} \mathrm{C}$. RNA-loading dye $(0.1 \mathrm{vol}$ of $9 \%$ glycerol, $10 \mathrm{mg} / \mathrm{mL}$ bromophenol blue and xylene cyanol, $5 \times$ TBE) was added to each sample. The RNA-protein complexes were resolved at $4^{\circ} \mathrm{C}$ for $15-20 \mathrm{~min}$ at $200 \mathrm{~V}$ on a pre-electrophoresed $(200 \mathrm{~V}$ for 20 min, $0.5 \times$ TBE running buffer) $1.5 \mathrm{~mm}$ $4 \%-5 \%$ polyacrylamide mini-gel (acrylamide:bis acrylamide of 36:1 or 70:1). After electrophoresis, gels were fixed in $10 \%$ isopropanol/7\% acetic acid, vacuum-dried, and RNA-protein interactions were detected by use of a PhosphorImager ${ }^{\circledR} 445$ SI (Molecular Dynamics, Sunnyvale, CA, USA).

In competition assays, the unlabeled RNA transcript was added to the extract for $10 \mathrm{~min}$ at $22^{\circ} \mathrm{C}$ before the radiolabeled transcript was added. Typically, the cold transcript is added in increasing molar excess (as many as 1000x) of the labeled transcript to demonstrate specific competition (see Figure 2, D and E). For experiments using sense and antisense DNA oligomers (sDNA and asDNA), the oligomer was incubated in molar excess (1-100-fold) with the labeled RNA for 10 min at $80^{\circ} \mathrm{C}$, cooled slowly to $22^{\circ} \mathrm{C}$ over $30 \mathrm{~min}$, before adding the extract (10). If an mRNA-asDNA hybrid forms in a region important for binding, RNA-protein complex formation will be abolished or reduced. The sDNAoligomer is used as a control.

\section{UV Cross-Linking Assay}

A larger amount of cytoplasmic protein and probe are required for UV cross-linking assay than for REMSA. For UV cross-linking assay, cytoplasmic extract $(20-40 \mu \mathrm{g})$ was incubated with $1-2 \times 10^{5} \mathrm{cpm}(10-20 \mathrm{pg})$ of radiolabeled transcript for $30 \mathrm{~min}$ at $22^{\circ} \mathrm{C}$ in a reaction volume of $20-30 \mu \mathrm{L}$ with CEB. RNase T1 (0.3-1 U) and heparin (final $5 \mu \mathrm{g} / \mu \mathrm{L}$ ) were added as for REMSA. The mixture was transferred to a microplate and placed $1.0 \mathrm{~cm}$ from the source and UV irradiated using a Stratalinker ${ }^{\circledR}$ UV Crosslinker $\left(3 \times 10^{5}\right.$ $\mu \mathrm{J}, 254-\mathrm{nm}$ bulbs) (Stratagene) on ice for 5-30 min. The mixture was then incubated with RNase A (final concentration $100 \mu \mathrm{g} / \mathrm{mL}$ ) (Roche Molecular Biochemicals, Mannheim, Germany) $(10,14)$ at $37^{\circ} \mathrm{C}$ for $15 \mathrm{~min}$. Sodium dodecyl sulfate (SDS) sample loading dye was added, samples were boiled for 3 min, and the proteins resolved for 20 min at $4^{\circ} \mathrm{C}$ and $200 \mathrm{~V}$ on a $1.5 \mathrm{~mm}$ SDS-polyacrylamide gel electrophoresis (PAGE) mini-gel pre-electrophoresed at $200 \mathrm{~V}$ for $20 \mathrm{~min}$. The percentage of acrylamide can be varied depending on the size of the RNA-protein complex that is to be resolved. A $10 \%$ acrylamide $(36: 1)$ gel is a good starting point to determine the size range of the majority of RNA-protein complexes. Gels of $250 \times 250 \times 1.5 \mathrm{~mm}$ were used when several proteins identified of similar $\mathrm{M}_{\mathrm{r}}$ had to be resolved.

\section{RESULTS AND DISCUSSION}

\section{Gel Dimension}

The mini-gel system was readily adapted for isolation of labeled probes. Resolution of several different fulllength radiolabeled transcripts was equal, if not better, using the mini-gel system that required only $10-20 \mathrm{~min}$ pre-electrophoresis and $15 \mathrm{~min}$ electrophoresis (e.g., TSH $\beta$ 3' UTR, IRE and EGF-R probes, A.M.Thomson and P.J. Leedman, unpublished results). This contrasted significantly with the $2-3$-h electrophoresis at $200 \mathrm{~V}$ and pre-electrophoresis of $1 \mathrm{~h}$ required for the standard $250 \times 250 \times 1.5 \mathrm{~mm}$ PAGE typically used to purify transcripts under denaturing conditions. Using mini-gels for probe isolation, a gel thickness of 1.5 and $0.75 \mathrm{~mm}$ provided the same results.

For the REMSA and UV cross-linking assay, an equivalent resolution of RNA-protein complexes previously detected using standard $250 \times 250 \mathrm{~mm}$ gels [e.g., IRE/IRP interactions (11), RNA-binding proteins binding to TSH $\beta$ (10) and EGF-R (13) mRNAs] was achieved on $1.5 \mathrm{~mm}$ PAGE minigels at $200 \mathrm{~V}$ for $15-20 \mathrm{~min}$, with 10-20 min pre-electrophoresis, compared with large $250 \times 250 \mathrm{~mm}$ gels (see Figures 1 and 2). However, for REMSA and UV cross-linking assay, optimal gel thickness was $1.5 \mathrm{~mm}$, as this resulted in a higher signal:noise ratio (data not shown). The change to mini-gels for all of these assays represented major timesavings, which enabled a much higher throughput of samples and reduced consumable costs.

\section{Probe Length and Probe to Protein Ratio}

Resolution of RNA-protein complexes is influenced by the ratio of $\left[\alpha-{ }^{32} \mathrm{P}\right] \mathrm{UTP}-$ labeled mRNA transcript to protein in the initial binding mixture. For example, incubation of $5 \times 10^{4} \mathrm{cpm}$ $(5 \mathrm{pg})$ of transcript with $10 \mu \mathrm{g}$ cytoplasmic extract (Figure 1A) is an ideal starting point for REMSA. Lower affinity 
RNA-protein complexes may require larger amounts of radiolabeled RNA (10-15 × 104 cpm, 10-15 pg) and/or protein for detection (Figure 1A, lanes 3 and 4). The REMSA and UV crosslinking assay also work efficiently with recombinant fusion protein and cytoplasmic extracts (7). For these assays, no changes are required in the protocol except to reduce the total amount of protein added, and $200 \mathrm{ng}$ is usually sufficient (A.M. Thomson and P.J. Leedman, unpublished observation).

There is a greater chance for generating nonspecific protein binding in REMSA and UV cross-linking assay when longer cRNA probes are used $(6,15)$, and shorter probes give clearer results. Our experience with the TSH $\beta$ probe il- lustrates the problems with longer probes. With the long 480 nt TSH $\beta$ probe, an ill-defined, nonspecific RNAprotein smear was evident (data not shown). In contrast, the shorter TSH $\beta$ probes (e.g., 3' UTR probe of only 70 nt) formed well-defined RNA-protein complexes that were readily characterized (Figure 1C and see Reference 10). In our experience, labeled RNA transcripts that are between $35-150 \mathrm{nt}$ in length are optimal for producing welldefined RNA-protein complexes.

\section{Reaction Volume}

Extensive experiments using several different probes with multiple cell lines demonstrated that smaller reaction

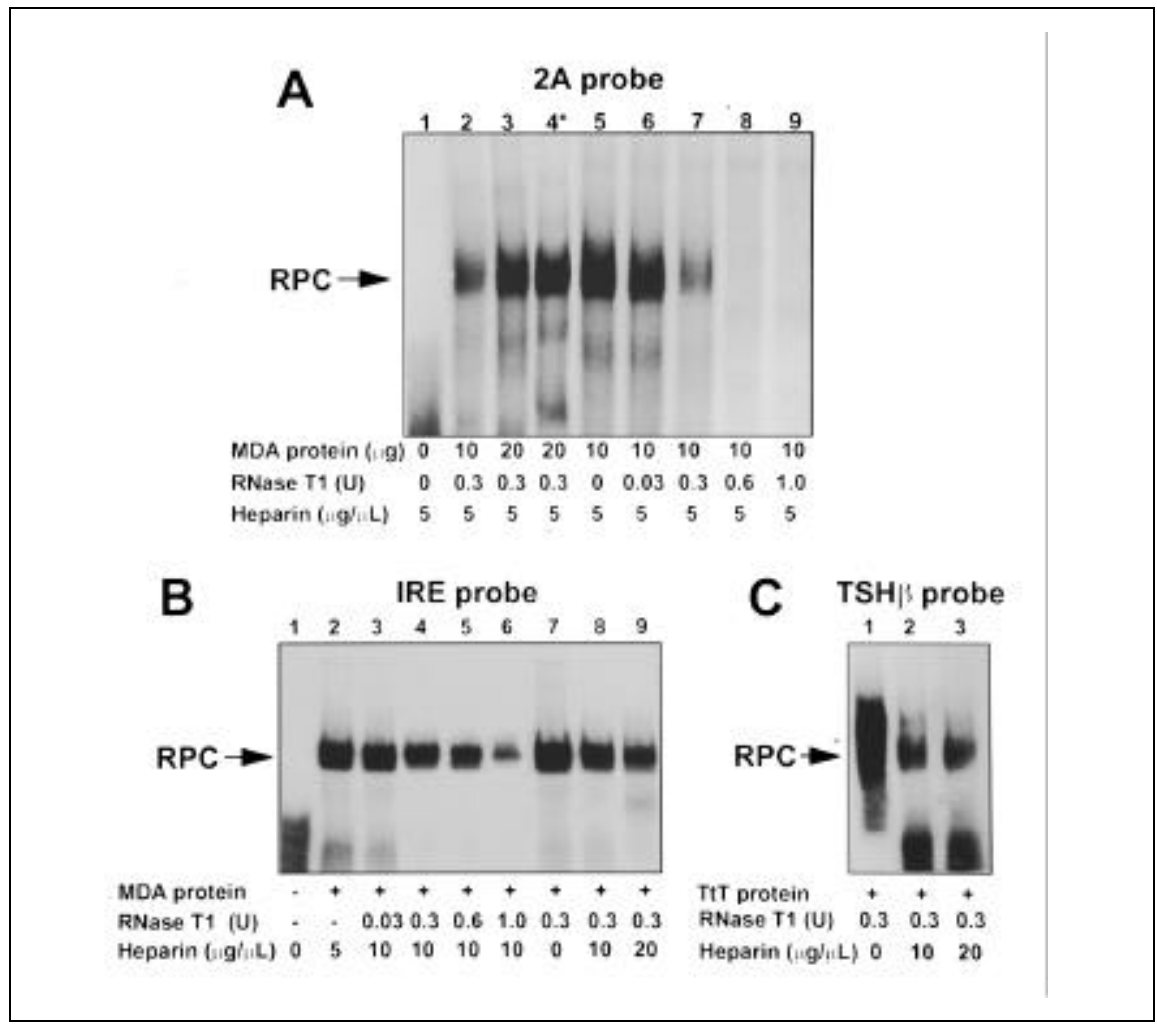

Figure 1. REMSA demonstrating the effect of varying the amounts of labeled probe, cytoplasmic protein extract, RNase T1 and heparin on RNA-protein complex detection. Cytoplasmic extracts were generated from MDA-MB-468 breast cancer cells (A and B) and murine TtT97 pituitary cells (C) and incubated with a human EGF-R probe (2A), a rat ferritin IRE probe or a rat TSH $\beta$ probe, before adding varying amounts of RNase $\mathrm{T} 1$ and heparin at the concentrations indicated. (A) Lanes 1-3: effect of increasing cytoplasmic extract concentration (where lane 1 is probe alone; lanes $2-3,10$ and $20 \mu \mathrm{g}$ MDA-MB-468 extract, respectively); lanes 3-4: increasing concentration of labeled EGF-R 2A-probe (5 pg or $5 \times 10^{4} \mathrm{cpm}$ per lane in all lanes, except lane $4 *$ in which $10 \mathrm{pg}$ or $1 \times 10^{5} \mathrm{cpm}$ were added); lanes 5-9: increasing RNase T1 concentration (0-1 U per sample) on formation of the 2A-RNA-protein complex. (B) Lanes 1-6: effect of increasing RNase T1 concentrations ( $0-1$ U per sample, lane 1 is probe alone) on high-affinity IRP/IRE RNA-protein complexes with 10 (+) $\mu \mathrm{g}$ MDA-MB-468 cytoplasmic protein extract; lanes 7-9: effect of increasing concentrations of heparin $(0,5$ and $10 \mu \mathrm{g} / \mathrm{mL})$ on IRE/IRP interaction (IRE probe, $5 \mathrm{pg}, 5 \times 10^{4} \mathrm{cpm}$ per lane). (C) Effect of increasing heparin concentration $(0,5$ and $10 \mu \mathrm{g} / \mu \mathrm{L})$ on TSH $\beta$ probe $\left(5 \mathrm{pg}, 5 \times 10^{4} \mathrm{cpm}\right.$ per lane) binding using TtT97 cell extract (10 $\left.\mu \mathrm{g}\right)$. 
volumes generate better-defined RNAprotein complexes in REMSA (A.M. Thomson and P.J. Leedman, unpublished observation). Ideally, the total volume should not exceed $20 \mu \mathrm{L}$, and $10 \mu \mathrm{L}$ is optimal. The more uniform the protein concentrations of different cytoplasmic extracts, the better is the likelihood of obtaining consistently reproducible results.

\section{RNase T1 Conditions}

RNase T1 attacks the 3' phosphate group of guanosine residues and cleaves the $5^{\prime}$ phosphate linkage in RNA molecules $(3,6,10,20)$. A general limitation of RNase $\mathrm{T} 1$ is that stable doublestranded regions of RNA are less susceptible to T1 attack. Therefore, the effectiveness of $\mathrm{T} 1$ for the purpose of reducing background in REMSAs not only depends on the stability of the RNA-protein complex but also on the nature of the RNA substrate $(6,20)$. When an RNA is bound to a protein(s), the protected region is resistant to RNase T1 digestion, although lowaffinity RNA-protein complexes are more susceptible to excessive RNase T1 treatment. Thus, varying the RNase T1 concentration used in REMSA (from ca. 0.2-1.0 U per reaction) can optimize characterization of RNA-protein complexes (Figure 1, A and B). Low-affinity RNA-protein complex interactions $\left(K_{\mathrm{d}}\right.$ ca. $10-100 \mathrm{nM}$ ) usually require a lower amount of RNase T1 (ca. 0.3 U per reaction) (Figure 1A), while high-affinity RNA-protein complexes $\left(K_{\mathrm{d}}\right.$ ca. $0.1-10$ $\mathrm{nM}$ ) are permissive of higher RNase T1 concentrations (up to ca. $1.0 \mathrm{U}$ per reaction) (Figure 1B). The difference between lanes 7 and 8 in Figure 1A illustrates the difference RNase T1 can have on specific RNA-protein complexes. This effect is very reproducible once the optimal RNase T1 concentration has been identified. Initial treatment with 0.3 U RNase T1 per $10 \mu \mathrm{g}$ cytoplasmic extract is recommended, although RNase T1 levels can be titrated up to 1 U RNase T1 per $10 \mu \mathrm{g}$ of cytoplasmic lysate, particularly when identifying high-affinity RNA-protein interactions (e.g., IRE/IRP) (Figure 1B, lane 6).

\section{Heparin Concentration}

Heparin is a negatively charged anion that mimics the RNA phosphate backbone and is added to reduce nonspecific protein binding to mRNA and background binding $(3,6,20)$. RNAbinding specificity is best studied with RNA competition studies. When using heparin, it is important to perform a dose-response assay with increasing concentrations to define the optimal concentration required for each probe used. A final concentration of $5 \mu \mathrm{g} / \mu \mathrm{L}$ heparin is the usual starting point to 
reduce nonspecific RNA-protein binding. Heparin can have a marked effect on RNA-protein complex detection for some probes (Figure 1C).

Using the TSH $\beta$ probe and cytoplasmic extracts from TtT97 pituitary cells, a large RNA protein smear was observed in the absence of heparin (lane 1). However, after the addition of increasing concentrations of heparin (5-10 $\mu \mathrm{g} / \mu \mathrm{L})$, nonspecific binding is considerably reduced and the RNAprotein complex better defined (Figure $1 \mathrm{C}$, lanes 2 and 3 ). In contrast, for some high-affinity interactions, even high doses of heparin have little effect on the complex. Figure 1B, lanes 7-9, illustrate that little change is observed for the IRE-IRP complex after high concentrations of heparin were included.

\section{Ratio of Bis to Acrylamide}

Modifying the acrylamide:bis-acrylamide ratio in REMSA may alter characterization of the RNA-protein complex, depending on the cell type and mRNA species used. We suggest initial REMSAs should be performed on PAGE with a ratio of acrylamide:bisacrylamide ratio of 36:1, which, in our hands, favors resolution of lower-affinity RNA-protein complexes (e.g., TSH $\beta$ mRNA, A.M. Thomson, J.M. Staton and P.J. Leedman, unpublished observation). Furthermore, gels produced with a higher ratio of acrylamide:bisacrylamide are considerably more convenient for technical handling and removal from glass plates before drying. Some RNA-protein complexes, however, are better characterized at a ratio of 70:1 (e.g., IRE/IRP) $(10,11)$. Consequently, REMSA and UV cross-linking assay should be performed with different ratios to optimize RNA-protein complex detection, depending on the cRNA probe being used.

\section{Competition REMSA to Determine RNA-Binding Specificity}

In addition to using unlabeled competitor RNA, unlabeled DNA oligomers can be used as competitors to map the region of RNA to which a protein specifically binds and to investigate binding specificity. For this procedure, short sense and antisense oligomers are routinely incubated individually with labeled RNA before addition of cytoplasmic extract (10). When the DNARNA hybrid contains part or all of the motif, RNA-protein complex formation is reduced or abolished. Figure 2A illustrates how this approach has successfully mapped the major protein binding site in a 70-nt TSH $\beta$ 3' UTR mRNA sequence. Sense and antisense oligomers were incubated with the TSH $\beta$ 3' UTR mRNA probe and REMSA performed with pituitary cell extract. Interestingly, oligomer 6 abolished binding, consistent with the $5^{\prime} 21$ nt of the 3' UTR containing the major binding motif. Oligomer 5 also reduced RNA-protein complex formation, but to a lesser degree, consistent with some involvement of this region in protein binding. This oligonucleotide mapping technique is an alternative to the RNase T1 footprinting assay $(3,12)$, which provides a composite map of the protected sequence. However, this assay requires more extensive preparation and is adequately described elsewhere (12).

\section{Regulated Binding of Proteins to RNA by REMSA}

Identification of regulated binding by specific RNA-binding proteins to a cognate cis-acting RNA element confers added functional relevance to any given interaction $(6,15,20)$. Several reports have identified a variety of compounds and cell treatments that modulate the binding activity of a wide variety of RNA-protein complexes (1,2,9-11,17), including hormones, cytokines, redox state and activators of protein kinase $C$ (e.g., phorbol 12-myristate 13-acetate [PMA]). The RNA-protein interactions involving the ferritin IRE and the IRPs represent a model system to examine the effects of regulatory inducers of gene expression. In essence, these inducers alter the binding of the IRP to the ferritin IRE, and as a consequence, they regulate the translation of the mRNAs for the L- and $\mathrm{H}$-subunits of the iron storage protein, ferritin.

PMA, an activator of protein kinase $\mathrm{C}$, regulates IRP binding to a ferritin IRE in extracts from HL-60 cells (Figure 2B). In our hands, PMA does not alter either IRP1 or IRP2 protein levels during the time course shown, as previ- 
ously demonstrated by Eisenstein et al. (2) and Schalinske and Eisenstein (17). Instead, the $\mathrm{B}_{\max }$ of IRP binding to the IRE in HL-60 cells increases by two- fold upon PMA treatment $(2,17)$. The IRP/IRE interaction is also regulated by other critically relevant inducers of ferritin translation, including change in re-

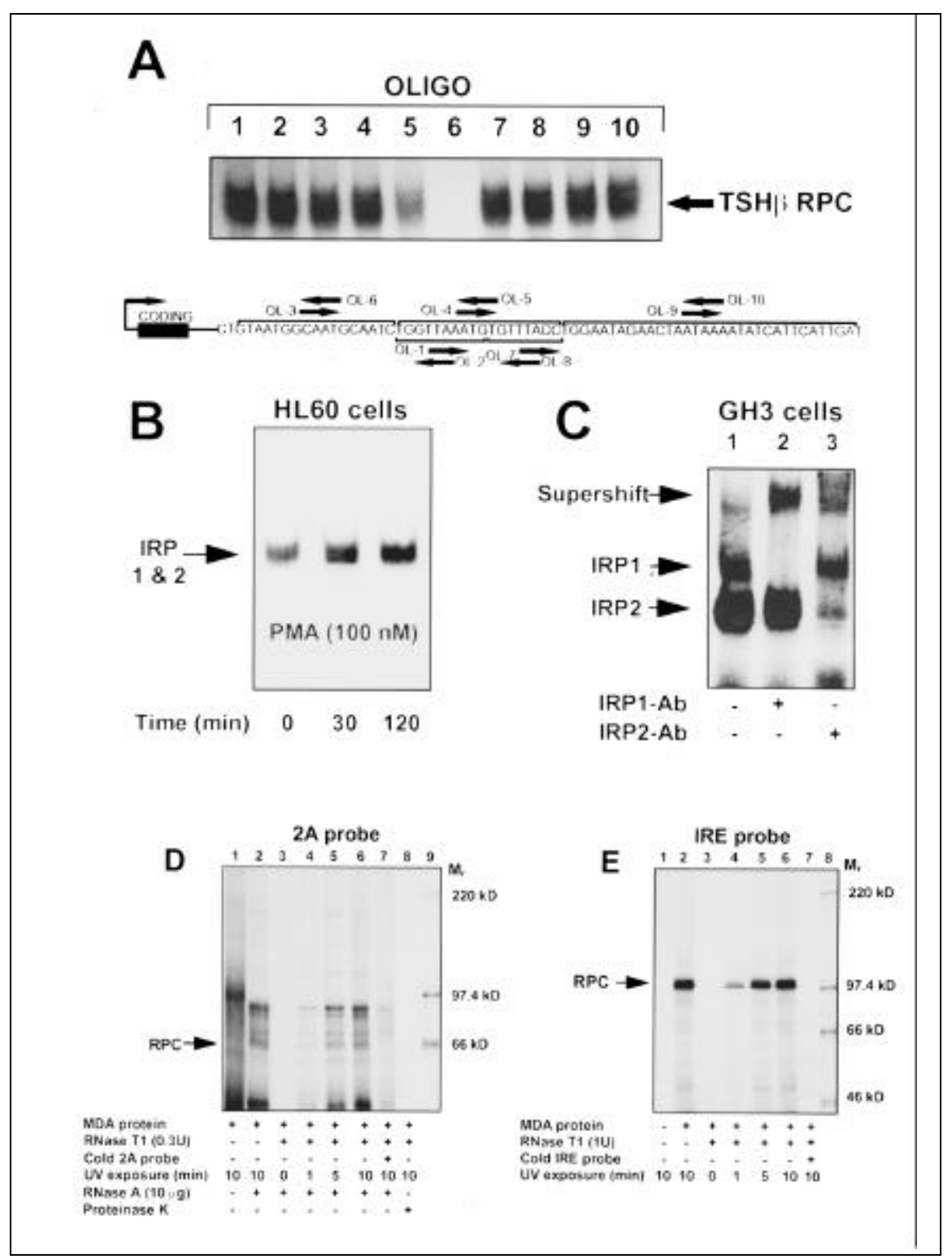

dox state (9) and thyroid hormone (11), each of which illustrates the complex nature of RNA-protein complex regulation in some cells. Thus, REMSA with the same probe comparing extracts derived from treated vs. untreated cells can reveal significant biological information about regulation of the RNAprotein interaction.

\section{Antibodies for Supershifting RNA- Protein Complexes}

Use of the REMSA supershift assay with appropriate antisera can readily confirm the identity of specific RNAbinding proteins within RNA-protein complexes. This method is particularly useful if multiple proteins are involved in RNA-protein complex formation. For example, IRP1-IRE and IRP2-IRE complexes from human tissue migrate identically in REMSA (Figure 2B), but Eisenstein et al. (2) and Schalinkse and Eisenstein (17) were able to distinguish the differential effect of PMA by using IRP1 and IRP2 supershifting antibodies. Figure $2 \mathrm{C}$ shows that each IRP antibody $(10 \mu \mathrm{g})$ supershifts a specific rat IRP isoform from a labeled ferritin IRE. Optimal supershifts depend on the RNA-protein-antibody interaction, and the antibody can be added before (7) the addition of labeled cRNA probe, or after the RNase T1 step (Figure 2C and References 2 and 17). The reaction mixture is then resolved by $5 \%$ PAGE.

\section{UV Cross-Linking of RNA-Protein Complexes}

UV irradiation induces covalent bonding between RNA and closely interacting protein molecules $(3,5,6$, 18-21). Before UV irradiation, samples

Figure 2. REMSA demonstrating (A) the utility of DNA oligomers for mapping the RNA-binding motif, (B) regulation of RNA-binding activity by PMA and (C) antibody supershift assay. UV cross-linking assays (D) and (E) showing effect of UV irradiation time, "cold competitors" and proteinase K treatment on the formation of RNA-protein complexes. (A) Use of DNA oligomers to define RNA-binding site. asDNA or sDNA oligonucleotides were hybridized to a labeled TSH $\beta$ probe ( $5 \mathrm{pg}, 5 \times 10^{4} \mathrm{cpm}$ per lane) at a molar ratio of 10:1 DNA:mRNA (can be up to 100:1 DNA:RNA), and subsequently REMSA was performed as above (see Materials and Methods) with $10 \mu \mathrm{g}$ of TtT97 extract. Lane numbers relate to the different oligonucleotides corresponding to the sequence of the 3' UTR of rat TSH $\beta$ mRNA. (B) Regulated IRP binding in HL60 cells. HL60 cells were treated with PMA (100 nM) for up to 120 min, and cytoplasmic protein extracts were prepared at various time points $(0,30,120 \mathrm{~min})$ from the cells. Cell extract $(10 \mu \mathrm{g})$ was incubated with $5 \times 10^{4} \mathrm{cpm} \mathrm{per} \mathrm{lane}(5 \mathrm{pg})$ IRE probe, and REMSA was performed as above. (C) REMSA for supershift of IRP1 and IRP2 with isoform-specific antibodies. Cytoplasmic extract (10 $\mu \mathrm{g}$ GH3 cells) was added to $5 \times 10^{4} \mathrm{cpm}(5 \mathrm{pg}$ ) of IRE probe, followed by RNase T1. Isoform-specific IRP antibody was then added (IRP1 $10 \mu \mathrm{g}$, lane 2 ; IRP2 10 $\mu \mathrm{g}$, lane 3 ) for $30 \mathrm{~min}$ at $22^{\circ} \mathrm{C}$, before addition of heparin followed by $5 \%$ PAGE as above. (D and E) Effect of UV cross-linking time and RNase A digestion on the UV cross-linking assay. Cytoplasmic extract $(20 \mu \mathrm{g})$ was mixed with $1 \times 10^{5} \mathrm{cpm}(10 \mathrm{pg})$ of either EGF-R 2A (D) or IRE (E) probe, followed by RNase T1 and heparin (as above). Reactions were then UV cross-linked for increasing times in a Stratalinker at a constant energy of $3 \times 10^{5} \mu \mathrm{J}$. The effect of RNase A digestion $(10 \mu \mathrm{g})$ post-UV cross-link is demonstrated in panel D, lanes 1 and 2. The effect of UV exposure time is demonstrated in panels D and E, lanes 3-6. In panels D and E, lane 7, excess unlabeled competitor ("cold") probe was added to the extract for $10 \mathrm{~min}$ at $22^{\circ} \mathrm{C}$ before the labeled probe. To demonstrate that RNA-protein complex formation was due to the presence of protein, IRE probe was incubated \pm MDA-MB-468 extract (panel E, lanes 1 and 2), and proteinase $\mathrm{K}$ (final concentration $100 \mu \mathrm{g} / \mathrm{mL}$ ) was added to the sample in panel $\mathrm{D}$, lane 8 for $30 \mathrm{~min}$ at $37^{\circ} \mathrm{C}$ before $\mathrm{UV}$ cross-linking (see text). 
are treated with RNase T1. A disadvantage may be the generation at this point of nonspecific RNA-protein complexes. Assays with excess unlabeled competitor RNA will determine the specificity of the RNA-protein moieties generated (see Reference 3; Figure 2D, lane 7 and Figure 2E, lane 7). For example, the UV cross-linking experiment in Figure 2D shows that the inclusion of RNase T1 reduces the background around a specific RNA-binding protein $(66 \mathrm{kDa})$ that interacts with labeled EGF-R mRNA 3' UTR cRNA probe (2A probe) (Figure 2D, lanes 1 and 4-6).

In this experiment, the inclusion of a cold $2 \mathrm{~A}$ probe confirms the identity of the $66 \mathrm{kDa}$ RNA-protein moiety from nonspecific binding of RNase T1 digestion products. For high-affinity interactions, e.g., IRE-IRP, RNase treatment may not be necessary (Figure 2E, lanes 2-7) Nonspecific competitors, such as the vector sequence without an insert, are useful (as are other unrelated sequences) for use as negative controls in cold competition experiments. Testing of mutations in the putative binding site of the labeled probe confers added specificity to RNA-protein interactions (8).

The optimum UV cross-link time varies for each probe and cell extract. However, $5-10 \mathrm{~min}$ of $3 \times 10^{5} \mu \mathrm{J}$ at 254 $\mathrm{nm}, 1.0 \mathrm{~cm}$ from the source is usually optimal (Figure 2D, lanes 3-6 and Figure 2E, lanes 1 and 3-6). The irradiation is performed on ice in 96-well CELLSTAR $^{\circledR}$ plates (Greiner Labortechnik, Frickenhausen, Germany), in which all samples are equidistant from the UV source. To improve resolution of RNAprotein complexes after UV cross-linking, we further digest the samples with RNase A, which cleaves $3^{\prime}$ of pyrimidine residues of RNA molecules (Figure 2D, lanes 1-2 and References 3,20,1). In conjunction with RNase T1 treatment, this can improve the signal:noise ratio of resolved bands and usually reduces the $\mathrm{M}_{\mathrm{r}}$ of the RNA-protein complex by up to $5 \mathrm{kDa}(3,20)$ (Figure 2D, lanes 1, 2 and 4-6). The optimum final RNase A concentration is approximately $100 \mu \mathrm{g} / \mathrm{mL}$ for a typical UV cross-linking assay using $1 \times 10^{5} \mathrm{cpm}(10 \mathrm{pg})$ probe and $30 \mu \mathrm{g}$ cytoplasmic extract (Figure 2, D and E).

We routinely perform the following step to optimize UV cross-linking of RNA probes to specific proteins: (i) To confirm that the complexes observed contain protein and are not the result of RNA-RNA interactions, we routinely incubate aliquots of the sample with proteinase $\mathrm{K}$ (final concentration 100 $\mu \mathrm{g} / \mathrm{mL}$ ) for $30 \mathrm{~min}$ at $37^{\circ} \mathrm{C}$ before $\mathrm{UV}$ cross-linking, resulting in abolition of the RNA-protein complex (Figure 2D, lane 8). This is clearly evident using the EGF-R 2A probe in Figure 2D. (ii) We vary the amount of radiolabeled transcript, which modulates detection of RNA-protein complex in UV cross- 
linking assay. An ideal starting mixture is $1 \times 10^{5} \mathrm{cpm}(10 \mathrm{pg})$ of probe and 20 $\mu \mathrm{g}$ cytoplasmic extract per reaction, although larger amounts may be required for low-affinity RNA-protein complexes. Because larger amounts of labeled cRNA are used in UV cross-linking assay compared to REMSA, larger amounts of RNase T1 may be required (up to $1.0 \mathrm{U}$ per sample). However, we routinely use $0.3 \mathrm{U}$ RNase $\mathrm{T} 1$ as a starting dose with $1 \times 10^{5} \mathrm{cpm}$ of probe and modify as required (Figure 2D).

In summary, this guide describes conditions for REMSA and UV crosslinking assay using mini-gels that are robust and work effectively in a wide variety of cell types and tissues with several different riboprobes. Critical parameters include: $(i)$ the requirement to gel purify the full-length transcript; (ii) maintain a small reaction volume; (iii) optimize RNase T1, heparin, RNase A, acrylamide:bis-acrylamide concentrations; (iv) and perform UV cross-linking assay under uniform conditions. A rapid method for using DNA oligomers to map the cognate RNAbinding motif is described. Antibody supershifts can readily be performed with high-affinity antibodies to identify specific proteins using REMSA. These guidelines should allow the rapid establishment of these techniques in the laboratory and facilitate effective troubleshooting in the assays.

\section{ACKNOWLEDGMENTS}

The authors would like to thank Dr. Betty Liebold for the generous provision of the IRP-2 antibody and the Medical Illustrations Department at Royal Perth Hospital for the prints. This work was in part supported by grants from the National Health and Medical Research Council of Australia, the Medical Research Fund of Western Australia, The Cancer Foundation of Western Australia and the Royal Perth Hospital Medical Research Foundation.

\section{REFERENCES}

1.Belasco, J. and G. Brawerman. 1993. Experimental approaches to the study of mRNA decay, p. 475-493. In J. Belasco and G. Brawerman (Eds.), Control of Messenger RNA Stability. Academic Press, New York.

2.Eisenstein, R.S., P.T. Tuazon, K.L. Schalinske, S.A. Anderson and J.A. Traugh. 1993. Iron-responsive element binding-protein: phosphorylation by protein kinase C. J. Biol. Chem. 268:27363-27370.

3.Enright, C. and B. Sollner-Webb. 1994. Ribosomal RNA processing in vertebrates: analysis of protein-RNA associations in rRNA processing, p. 155-164. In S.J. Higgins and B.D. Hames (Eds.), RNA Processing: A Practical Approach, Vol. II. Oxford University Press, Oxford.

4.Gillis, P. and J.S. Malter. 1991. The adenosine-uridine binding factor recognizes the AUrich elements of cytokine, lymphokine, and oncogene mRNAs. J. Biol. Chem. 266:31723177.

5.Gu, W. and N.B. Hecht. 1996. Translation of a testis-specific $\mathrm{Cu} / \mathrm{Zn}$ superoxide dismutase (SOD-1) mRNA is regulated by a $65 \mathrm{KDa}$ protein which binds to its 5' UTR. Mol. Cell. Biol. 16:4535-4543.

6.Higgins, S.J. and B.D. Hames (Eds). 1994 RNA Processing: A Practical Approach, Vols. I and II. Oxford University Press, London.

7.Joseph, B., M. Orlian and H. Furneaux. 1998. p21WAF1 mRNA contains a conserved element in its 3 -untranslated region that is bound by the Elav-like mRNA-stabilizing proteins. J. Biol. Chem. 273:20511-20516.

8.Kikinis, Z., R.S. Eisenstein, A.J.E. Bettany and H.N. Munro. 1995. Role of RNA secondary structure of the IRE in translational regulation of ferritin synthesis. Nucleic Acids Res. 23:4190-4195.

9.Klausner, R.D., T.R. Rouault and J.B. Harford. 1993. Regulating the fate of mRNA: the control of cellular iron metabolism. Cell 72:1928.
10.Leedman, P.J., A.R. Stein and W.W. Chin. 1995. Regulated specific protein binding to a conserved region of the 3'-untranslated region of thyrotropin $\beta$-subunit mRNA. Mol. Endocrinol. 9:375-387.

11.Leedman, P.J., A.R. Stein, W.W. Chin and J.R. Rogers. 1996. Thyroid hormone modulates the interaction between iron regulatory proteins and the ferritin mRNA iron-responsive element. J. Biol. Chem. 271:12017-12023.

12.Liebold, E.A. and H. Munro. 1988. Cytoplasmic proteins bind in vitro to a highly conserved sequence in the $5^{\prime}$ untranslated region of ferritin heavy- and light-subunit mRNAs. Proc. Natl. Acad. Sci. USA 85:2171-2175.

13.McCulloch, R.K., C.E. Walker, A. Chakera, J. Jazayeri and P.J. Leedman. 1998. Regulation of EGF-receptor expression by EGF and $\mathrm{TGF} \alpha$ in epidermoid cancer cells is cell typespecific. Int. J. Biochem. Cell Biol. 30:12651278.

14.Milligan, J.F., D.R. Groebe, G.W. Witherell and O.C. Uhlenbeck. 1987. Oligoribonucleotide synthesis using T7 RNA polymerase and synthetic DNA templates. Nucleic Acids Res. 15:8783-8789.

15.Nagai, K. and W. Mattaj (Eds.). 1996. RNAProtein Interactions, 1st ed. Oxford University Press, London.

16.Nakagawa, J., H. Waldner, S. MeyerMonard, J. Hofsteenge, P. Jeno and C. Moroni. 1995. AUH, a gene encoding an AU-specific RNA binding protein with intrinsic enoyl-CoA hydratase activity. Proc. Natl. Acad. Sci. USA 92:2051-2055.

17.Schalinske, K.L. and R.S. Eisenstein. 1996. Phosphorylation and activation of both iron regulatory proteins 1 and 2 in HL-60 cells. J. Biol. Chem. 271:7168-7176.

18. Walker, J., O. de Melo Neto and N. Standart. 1998. Gel retardation and UV-cross-linking assays to detect specific RNA-protein interactions in the $5^{\prime}$ or $3^{\prime}$ UTRs of translationally regulated mRNAs. Methods Mol. Biol. 77:365-378.

19.Will, C.L., B. Kastner and R. Luhrmann. 1994. Analysis of ribonucleoprotein interactions, p. 141-178. In S.J. Higgins and B.D. Hames (Eds.), RNA Processing: A Practical Approach, Vol. I. Oxford University Press, Oxford.

20.Wilson, G.M. and G. Brewer. 1999. The search for trans-acting factors controlling messenger RNA decay. Prog. Nucleic Acid Res. Mol. Biol. 62:257-291.

21.Zhang, W., B.J. Wagner, K. Ehrenman, A.W. Schaefer, C.T. De Maria, D. Crater, K. De Haven, L. Long and G. Brewer. 1993. Purification, characterization, and cDNA cloning of an AU-rich element RNA-binding protein, AUF1. Mol. Cell. Biol. 13:7652-7665.

Received 9 March 1999; accepted 12 July 1999.

Address Correspondence to:

Dr. Peter J. Leedman

Laboratory for Cancer Medicine and

University Department of Medicine

Royal Perth Hospital

Box X2213 GPO

Perth 6001, WA, Australia

Internet:peterl@cyllene.uwa.edu.au 